\title{
Pengembangan Ekonomi Kreatif Berbasis Kearifan Lokal Besiang Air dalam Meningkatkan Pendapat Penganyam (Studi Kasus di Kecamatan Sei Kepayang Barat)
}

\author{
Khairani Alawiyah Matondang ${ }^{1}$ \\ ${ }^{1}$ Fakultas Ekonomi, Universitas Negeri Medan \\ Email: baguskaran@gmail.com
}

\begin{abstract}
Abstrak
Studi ini bertujuan untuk meningkatkan kualitas sumber daya manusia berbasis kearifan lokal kerajinan besiang air di Kecamatan Sei Kepayang Barat. Keberadaan ekonomi kreatif sebagai upaya menyelaraskan dan menjawab permasalahan penggangguran, kemiskinan, eksploitasi alam yang menyebabkan terjadinya ketimpangan sosial maupun pertumbuhan ekonomi. Salah satu cara untuk mengatasi permasalahan ini dengan memadukan sektor ekonomi dan kearifan lokal untuk dapat memacu tumbuhnya kegiatan perekonomian yang pada akhirnya dapat meningkatkan taraf hidup masyarakat. Dalam studi ini menggunakan pendekatan deksriktif kualitatif dengan metode pengumpulan data dilakukan melalui observasi, interview. Hasil penelitian menyatakan bahwa kerajinan besiang air terhadap masyarakat belum memiliki efek multilpier dibidang ekonomi. Salah satunya hambatan dalam pengembangan ekonomi kreatif dibidang kerajinan besiang air mengalami kemandekan regenerasi penerus akibat tergerusnya kearifan lokal di masyarakat. Selain itu, kurangnya kreativitas dan inovasi menjadikan usaha kerajinan besiang air mengalami stagnan.
\end{abstract}

Keywords: ekonomi kreatif, kearifan lokal, besiang air 


\section{PENDAHULUAN}

Masyarakat memiliki kebiasaan tersendiri dalam mengelola alam dan lingkungan. Kebiasaan-kebiasaan ini membentuk menjadi sebuah kearifan lokal. Kearifan lokal yang ada di masyarakat memiliki pengaruh dalam kehidupan ekonomi dan sosial secara temurun.

Kearifan lokal merupakan intervensi evolusi budaya dan karya budaya yang melukiskan bentuk kekhasan atau keunikan dari setiap daerah (Aryo, 2011). Keunikan dari setiap daerah bergantung pada potensi sumberdaya alam dan lingkungan.

Kearifan lokal mengandung nilai-nilai universal, yang terlihat dalam kehidupan sehari di masyarakat. Maka tidak mengherankan banyak kearifan lokal memiliki peluang untuk dikembangkan menjadi industri kreatif dengan menambahakan kreativitas atau inovasi.

Salah satu cara untuk pengembangan ekonomi kreatif melalui usaha kerajinan lokal yang memberikan potensi lokal untuk lebih berkembang. Salah satu harmonisasi manusia dengan lingkungan adalah memanfaatkan tanaman besiang air dalam bentuk anyaman tikar. Potensi anyaman besiang air dapat memberikan dampak khusus bagi perekonomi masyarakat sekitar. Usaha kerajinan anyaman besiang air memberikan dampak penciptaan lapangan kerja, peningkatan pendapatan, penguatan rasa solidaritas masyarakat.

Tentu saja, pengembangan ekonomi kreatif berbasis kearifan lokal tidak terlepas dari peran semua pihak. Ford (2008) mengatakan pengembangan ekonomi kreatif merupakan integrasi antara lembaga publik dan swasta dengan pertumbuhan perusahaan dan tujuan sosial. Faktanya, anyaman kerajinan besiang air telah lama menjadi salah satu potensi kearifan lokal yang ada di Kecamatan Sei Kepayang Barat.

Kerajinan anyaman besiang air telah menjadi ekonomi kreatif berfokus pada keunggulan suatu kearifan lokal yang dapat menghasilkan suatu produk dengan mengandalkan keahlian di daerah ini.

Dalam perjalanannya, penggunaan kerajinan anyaman besiang air mengalami pergeseran yang siginifikan dalam kehidupan masyarakat. Padahal dikaji lebih mendalam ekonomi kreatif berbasis besiang air merupakan salah satu bagian dari kearifan lokal yang
NIAGAWAN Vol 7 No 3 November 2018 berkembang di masyarakat dan merupakan kebudayaan yang diadaptasi dari lingkungan.

Berdasarkan latar belakang permasalahan diatas, maka dirumuskan masalah bagaimana meningkatkan kualitas sumber daya manusia berbasis kearifan lokal kerajinan besiang air di Kecamatan Sei Kepayang Barat?

\section{TINJAUAN PUSTAKA}

Kearifan Lokal

Moendardjito dalam Ayathrohedi (1986) mengatakan bahwa unsur budaya daerah sebagai kearifan lokal yang potensial untuk dikembangkan karena telah terbukti mampu bertahan sampai saat ini.

Sebagai produk budaya di masa lalu, kearifan lokal tertanam dan diikuti oleh masyarakat sebagai gagasan yang bersifat bijaksana. Gagasan dari kearifan lokal akan mengusung masyarakat untuk semakin berbudi luhur ( Moendardjito dalam Ayathrohedi,1986).

Kearifan lokal dapat juga diartikan sebagai nilai, tingkah laku, karya akal budi, perasaan mendalam dananjuran untuk kebaikan dan kemuliaan manusia ( Azizah dkk, 2017)

\section{Ekonomi Kreatif dan Kearifan Lokal}

Dalam perekonomian nasional, pengembangan ekonomi kreatif tidak terlepas dari keragaman sosio budaya yang tersebar di seluruh pelosok daerah. Pengaruh keragaman budaya sosio budaya ini menjadi pondasi pengembangan industri kreatif. Beragam budaya yang ada menunjukkan tingginya kreativitas dan inovasi yang ada di masyarakat.

Budaya harus menjadi basis pengembangan ekonomi kreatif melalui kearifan lokal yang mengandung nilai-nilai bermakna. Selanjutnya nilai-nilai bermakna ini diwujudkan dalam bentuk fisik baik berupa sebuah produk yang menjadi ciri khas dari suatu daerah.

Dalam perjalanannya, ekonomi kreatif untuk dapat berkembang tidak hanya dilihat dari sisi ekonomi, namun unsur budaya yang ada dai masyarakat juga memiliki peranan penting. Dalam budaya lokal terdapat ide-ide kreatif sebagai produk budaya bila diterjemahkan ke dalam bentuk fisik berupa produk kreatif daerah. Ekonomi kreatif tidak terlepas dari unsur budaya, dimana ide kreatif yang muncul adalah produk budaya.

Produk budaya ini memiliki potensi bernilai ekonomi bila dikemas dan dipasarkan untuk menambah pendapat masyarakat. Tentu 
saja, semua ini harus didukung sepenuhnya oleh semua pihak yang terkait. Potensi produk ini dapat menjadi nilai jual suatu daerah yang bisa dikembangkan, dengan menambahkan unsur kreativitas dengan sentuhan teknologi.

Keberhasilan pengembangan ekonomi kreatif adalah mampu mengintergrasikan teknologi, informasi dengan tetap mempertahankan kearifan lokal yang ada untuk meningkatkan penghidupan yang lebih layak dalam mencapai keunggulan, menciptakan lapangan pekerjaan, serta memberikan peluang untuk lebih berkembang.

Hal ini sejalan dengan dengan cita-cita pembangunan ekonomi untuk mengetaskan kemiskinan., yang direalisasikan dengan mengedepankan kreativitas sumberdaya manusia untuk menciptakan produktivitas yang mampu memberikan peningkatan pendapatan.

\section{METODE PENELITIAN}

Penelitian ini merupakan kombinasi dari penelitian penjelasan (explanatory research) dan penelitian deksriktif. Penelitian ini melakukan wawancara sebagai alat pengumpulan data pokok untuk mengkaji pengembangan ekonomi kreatif berbasis kearifan lokal.

Tempat Penelitian

Penelitian ini dilakukan secara sengaja (purposive) di Desa Sei Lendir Kecamatan Sei Kepayang Barat, Kabupaten Asahan. Peneliti menganalisis berbagai fakta mengenai korelasi tergerusnya ekonomi kreatif besiang air di masyarakat.

Waktu Penelitian

Penelitian ini dilakukan selama satu bulan untuk menganalisis berbagai fakta mengenai korelasi antara tergerusnya ekonomi kerajinan Besiang Air, dengan dekandensi moral budaya dan pemahaman kearifan lokal yang dialami masyarakat.

\section{Populasi dan Sampel}

Populasi dan sampel dalam penelitian ini adalah penganyam kerajinan Besiang Air yang berjumlah sebanyak sepuluh orang.

Teknik Pengumpulan Data

Dalam penelitian ini menggunakan data primer yang diperoleh dari observasi dan wawancara kepada reponden yang telah ditentukan.

\section{Metode Analisis Data}

Penelitian ini menggunakan metode kualitatif, dimana data-data yang bersifat kualitatif digambarkan dengan kata-kata menurut kategorinya untuk memperoleh kesimpulan (Arikunto, 1998). Selanjutnya, data-data yang berupa pernyataan, keterangan dianalisis untuk menjawab permasalahan yang ada.

Kemudian peneliti menyimpulkan pemecahan permasalahan yang dialami dalam pengembangan ekonomi kreatif berbasis besiang air. Perpaduan antara kearifan lokal dan modernisasi besiang air, akan melestarikan bahan alam menjadi komoditas perekonomian masyarakat Kecamatan Sei Kepayang Barat tanpa meninggalkan filosofi kearifan lokal didalamnya.

\section{HASIL DAN PEMBAHASAN}

Kerajinan anyaman besiang air merupakan usaha kerajinan rumah tangga yang menjadi tradisi turun temurun dari generasi ke generasi di Kecamatan Sei Kepayang Barat. Kegiatan ekonomi yang berbasis turun temurun akan mengalami keajegan (Aryo, 2011).

Kerajinan anyaman besiang air memiliki keunikan dan kekhasan tersendiri. Sayangnya, potensi ini terhambat dan tergerus arus modernitas di kalangan masyarakat yang memberikan dampak tergerusnya eksistensi budaya kerajnan besiang air.

Padahal bahan baku basing air sangat melimpah dan dapat dikembangkan untuk menjadi kegiatan ekonomi kreatif dengan berbasis kearifan lokal. Andai saja pemerintah ikut dan peran untuk mengembangkan usaha ini, maka masalah penggangguran akan teratasi.

Rendahnya pendidikan menjadi salah satu kendala, untuk mengembangkan kerajinan dari basiang air. Oleh karena diperlukan pelatihan yang terkait dengan potensi ini. Disamping itu, kendala keuangan juga menjadi salah satu faktor penghambat kemajuan usaha kerajinan ini.

Selain potensi ekonomi, kerajinan besiang air juga dapat memupuk solidaritas dan rasa kekeluargaan antara masyarakat setempat dikarenakan adanya interaksi yang intens saat menganyam antar individu. Tentu saja, hal ini memberikan dampak positif untuk menciptakan kerukunan yang kukuh dan menimbulkan rasa aman di lingkungan tersebut. 
NIAGAWAN Vol 7 No 3 November 2018

Kesederhanaan merupakan kunci keharmonisan manusia dengan alam. Usaha kerajinan yang dibangun melalui pemanfaatan besiang air sebagai sebuah strategi harmonisasi manusia dengan alam. Usaha kerajinan berbasis pandan tidak semata-mata hanya mengekspoiltasi hasil tanaman, namun melakukan pemilihan terdapat batang basiang air yang dapat digunakan untuk kerajinan.

\section{Sumber Daya Pengayam Kerajinan}

Ketika kebutuhan hidup semakin mengalami peningkatan, sementara akses keuangan terbatas, maka kegiatan menganyam tradisonal menjadi pilihan hidup. Pelestarian anyaman besiang air menjadi alasan pengayam tradisional untuk tetap bertahan sampai saat ini. Pemahaman dan kecintaan terhadap kearifan lokal anyaman besiang air kembali pada tempatnya. Bukan tidak mungkin profesi menganyam akan kembali digeluti sebagai bentuk kecintaan dan komitmen untuk melestarikan eksistensi anyaman besiang air sebagai warisan budaya.

Pada saat ini, penganyam hanya mampu memasarkan produknya dalam skala kecil, dimana pemesanan produknya hanya dari mulut ke mulut. Pemasaran produk kerajinan ini masih sebatas dalam desa saja. Lama pengerjaan pembuatan anyaman ini memakan waktu sebulan untuk menghasilkan satu buah produk. Produk kerajinan anyaman yang dihasilkan masih sebatas produk yang sederhana. Harga sebuah produk anyaman dihargai Rp. 100.000

Namun, kenyataan Kerajinan anyaman besiang air mengalami mati suri, dimana para pengrajin tidak pernah mendapat pelatihan untuk mengembangkan kerajinan tersebut menjadi produk lain.

Oleh karena itu, masyarakat yang bersifat homogen dan dapat dipengaruhi dengan cara yang mutual. Salah satu peluang yang dapat dimanfaatkan oleh masyarakat untuk melestarikan anyaman besiang air melalui model entertaining selling. Model ini dapat merangkap sebagaiteknik pemasaran produk kerajinan, bisa dilakukan melalui pameran bentuk kerajinan yang diadakan pemerintah atau memasarkan melalui dunia maya yang saat ini lagi populer.

Semakin banyak masyarakat mengenal bahwa anyaman besiang air bukan hanya nyaman dari tanaman, tetapi juga sebuah karya seni yang pantas dihargai dengan harga yang layak, maka kisaranRp. 100.000 bukan menjadi harga yang mahal. Harga memberikan makna filosofi bagi pemakainya, juga akan lebih menggairahkan penganyam untuk lebih bekerja dengan keras menghasilkan kerajinan yang berkualitas terbaik.

Semua produk kerajinan dibuat dengan tangan, anyaman dilakukan satu per satu, dengan menggunakan bahan besiang air yang sangat natural dan unik menampilkan kekayaan budaya lokal. Mengoptimalkan usaha dan strategi pemasaran produk kerajinan besiang air merupaka salah satu faktor utama yang akan mempengaruhi perkembangan dan kesuksesan ekonomi kreatif besiang air.

Pengembangan kerajinan besiang air sebagai ekonomi kreatif dilakukan melalui mengembangkan inovasi produk sesuai dengan kebutuhan masyarakat, inovasi pemasaran produk yang sesuai dengan perkembangan teknologi.

\section{KESIMPULAN DAN SARAN}

Manusia sebagai makhluk cipta Kuasa yang sempurna, memiliki pola pikir yang menghasilkan karya budaya yang mencerminkan kearifan lokal. Kearifan lokal memiliki potensi ekonomi kreatif yang dapat meningkatkan kesejahteraan manusia. Tanaman besiang air merupakan salah satu kearifan lokal yang dapat dikembangkan menjadi ekonomi kreatif. Kerajinan besiang air semakin hari mengalami penggerusan nilai moral dan filsofi harmoni yang melekat. Oleh karena itu,perlu ditanggulangi melalui penanaman kembali nilainilai moral dan filosofi harmoni yang melekat pada setiap efek multiplier anyaman besiang air hingga menjadi sebuah kerajinan.

Untuk mewujudkan sebuah generasi budaya baru yang menjunjung tinggi semangat nasional, perlu dilakukan usaha yang optimal melalui peningkatan sumber daya manusia. Pada kerajinan besiang air, sumber daya manusia mencakup sumberdaya pengrajin dan sumber daya pemasaran yang saling berkontribusi untuk membangun budaya dan memajukan kerajinan besiang air sebagai usaha lokal yang bercita rasa klasik bagi masyarakat.

Namun, potensi basing air perlu mendapat perhatian penuh dari pemerintah maupun masyarakat sekitar. Pemerintah dapat memberikan pelatihan kepada penganyam untuk dapat mengembangkan ide-ide kreatif dan inovasi untuk mengembangkan jenis-jenis 
kerajinan yang dapat dihasilkan dari besiang air. Selain itu bantuan, modal juga sangat diperlukan penganyam untuk membeli peralatan yang dibutuhkan untuk kegiatan proses produksi. Pemasaran produk juga perlu dikembangkan dengan mengikutkan produk kerajinan anyaman besiang air sebagai salah satu bentuk ekonomi kreatif berbasis kearifan lokal yang ada di Kecamatan Sei Kepayang Barat.

\section{REFERENSI}

Angga Aryo W, 2011, The Tradmodernition: Gerakan Glokalisasi Berbasis Kearifan Lokal Batik Banyumas, Karya Tulis Ilmiah, Juara Harapan 1 UNS.

Arikunto, S., 2002, Prosesdur Penelitian Suatu Pendekatan Praktek, Renika Cipta.

Ayatrohaedi, 1986, Kepribadian Budaya Bangsa (local Genius), Pustaka Jaya, Jakarta.

Azizah, Siti Nur, dan Muhfiatun, 2017. Pengembangan Ekonomi Kreatif Berbasis Kearifan Lokal Pandanus Handicraft (Study Case di Pandanus Nusa Sambisari Yogyakarta). APLIKASIA : Jurnal Aplikasi Ilmu-ilmu Agama, Volume 17 Nomor.2, 2017, page 63-78

Jo Foord, 2008, Strategies for Creative Industries: an International Review, Creative Industries Journal Volume 1 Number 2 Cities Institute, London. Metropolitan University 